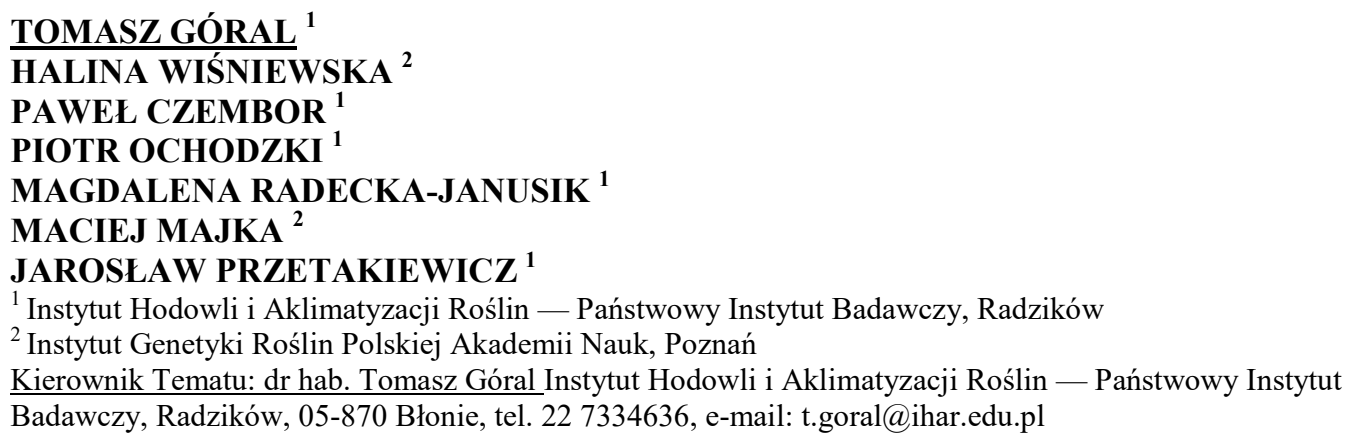

Prace zostaty wykonane $w$ ramach badań podstawowych na rzecz postępu biologicznego $w$ produkcji roślinnej na podstawie decyzji Ministra Rolnictwa i Rozwoju Wsi nr HOR.hn.802.19.2018, Zadanie 6.

\title{
Poszukiwanie oraz wykorzystanie markerów fenotypowych, metabolicznych i molekularnych do badania typów odporności na fuzariozę kłosów u form pszenicy o zróżnicowanej podatności
}

Identification and application of phenotypic, metabolic and molecular markers in studies of types of resistance to Fusarium head blight in winter wheat accessions differing in resistance

Słowa kluczowe: Fhb1, Fusarium, fuzarioza kłosów, markery molekularne, mykotoksyny, odporność, pszenica

\section{CELE PROJEKTU}

1. Ocena stopnia porażenia kłosów genotypów pszenicy ozimej przez Fusarium celem wyboru form odpornych pod względem odporności typu 1 oraz 2 na fuzariozę kłosów.

2. Ocena odporności na uszkodzenie ziarniaków przez Fusarium (typ odporności 3) oraz tolerancji genotypów pszenicy na fuzariozę kłosów (typ odporności 4) celem wyboru form odpornych.

3. Określenie zawartości ergosterolu (wskaźnik zawartości grzybni) oraz toksyn fuzaryjnych w ziarnie (typ odporności 5) wybranych genotypów pszenicy 
wykazujących podwyższoną odporność na porażenie kłosa i uszkodzenie ziarniaków przez Fusarium.

4. Uzyskanie pokolenia $\mathrm{F}_{3} \mathrm{BC}_{2}$ pięciu kombinacji krzyżówkowych pszenicy ozimej po wcześniejszej selekcji molekularnej osobników pokolenia $\mathrm{F}_{2} \mathrm{BC}_{2}$ na obecność genu $F h b 1$ odporności na fuzariozę kłosa.

\section{MATERIAŁY I METODY}

Odporność na fuzariozę kłosów genotypów pszenicy testowano w warunkach polowych w IHAR Radzików oraz w IGR PAN w Poznaniu (Cerekwica). Materiał badawczy stanowiły genotypy, które wykazały odporność w roku 2017 oraz nowe niebadane dotychczas genotypy. Formy wzorcowe stanowiły odmiany i linie odporne; wybrane genotypy o wysokiej podatności na porażenie kłosa; współczesne odmiany o wysokim plonie. Kłosy pszenicy w fazie kwitnienia opryskiwano zawiesiną zarodników Fusarium culmorum. Oceniano porażenie kłosów wyliczając indeks fuzariozy kłosów (IFK).

W celu określenia odporności typu 1 kłosy pszenicy opryskiwane były zawiesiną zarodników F. culmorum. Oceniana była liczba punktów infekcji na kłosach. W celu określenia odporności typu 2 zastosowana była metoda inokulacji punktowej. Nasilenie fuzariozy kłosów oceniane było poprzez określanie liczby kłosków z objawami choroby.

Prowadzone były doświadczenia infekcyjne w 5 punktach doświadczalnych (Dębina, Nagradowice, Polanowice, Smolice, Strzelce). W doświadczeniach tych wysiano nowe genotypy, których odporność nie była dotychczas badana. Metodyka doświadczenia była podobna w Radzikowie i Poznaniu.

Proporcja ziarniaków uszkodzonych przez Fusarium była określana wizualnie poprzez podział próby ziarniaków na ziarniaki zdrowe i ziarniaki z objawami porażenia przez Fusarium (Argyris i in., 2003). Wyliczono wartość FDK w oparciu o masę ziarniaków uszkodzonych (FDK masa) oraz ich liczbę (FDK liczba) w odniesieniu do masy lub liczebności całej próby. Określona została względna wartość komponentów plonu ziarna w odniesieniu do prób kontrolnych.

W wybranych próbach ziarna pszenicy z doświadczeń z roku 2017 analizowana była zawartość DNA F.culmorum. Wykorzystano technikę real-time PCR zgodnie z metodyką opisaną przez Nicolaisen i in. (2009). Wyliczono względną zawartość DNA F. culmorum w stosunku do DNA pszenicy (pg/ $\mu \mathrm{g})$.

Ziarno z genotypów o najwyższej odporności analizowano pod względem zawartości ergosterolu oraz toksyn fuzaryjnych. Zawartość ergosterolu określona była metodą wysokosprawnej chromatografii cieczowej (Perkowski i in., 2007, 2008). Zawartość trichotecenów z grupy B (deoksyniwalenol [DON], 3-acetyl deoksyniwalenol [3AcDON], 15-acetyl deoksyniwalenol [15AcDON], niwalenol [NIV]) analizowano przy wykorzystaniu techniki chromatografii gazowej (Góral i in., 2019). Zawartość zearalenonu (ZEN) oznaczano za pomocą ilościowego testu ELISA AgraQuant ${ }^{\circledR}$ ZON 40/1000 zgodnie z procedurą podaną przez producenta. 


\section{Selekcja wspomagana markerami molekularnymi (MAS)}

Materiałem wykorzystanym $\mathrm{w}$ badaniach były rośliny pokolenia $\mathrm{F}_{2} \mathrm{BC}_{2}$ pochodzące z pięciu kombinacji krzyżówkowych. Dawcą genu odporności na fuzariozę była linia AIII62/1, natomiast biorcami - linie SMH8527, DL414/10, STH1178, MIB11262 oraz NAD10041. W ramach tematu przeanalizowano łącznie 600 roślin — po $120 \mathrm{z}$ każdej kombinacji. $\mathrm{W}$ pierwszym etapie selekcji rośliny pokolenia $\mathrm{F}_{2} \mathrm{BC}_{2}$ testowano w poszukiwaniu osobników homozygotycznych pod względem genu odporności Fhbl (w typie rodzica-dawcy), na podstawie analizy polimorfizmu markerów SSR sprzężonych $\mathrm{z}$ genem, tj. UMN10 lub cfb6033. Polimorfizm badano również w loci markerów flankujących dystalnie (gwm389) i proksymalnie (gpw3248), mając na celu selekcję homozygot $\mathrm{w}$ typie rodzica wypierającego. Po tym etapie zawężono pulę roślin do osobników, które były homozygotami pod względem genu odporności Fhbl (w typie rodzica-dawcy) oraz (w miarę możliwości) homozygotami w typie rodzica wypierającego pod względem loci markerów flankujących. W celu potwierdzenia wyników selekcji przetestowano ponownie loci wymienionych wcześniej markerów oraz dodatkowo zbadano polimorfizm kolejnych dwóch markerów flankujących, tj. gwm493 i barc12, położonych bliżej genu Fhbl.

Po zakończeniu analiz molekularnych wybrane rośliny pokolenia $\mathrm{F}_{2} \mathrm{BC}_{2}$ zostały wykorzystane do uzyskania pokolenia $\mathrm{F}_{3} \mathrm{BC}_{2}$. Rośliny zostały poddane jarowizacji ( 8 tygodni w temp. $4^{\circ} \mathrm{C}$ ), a następnie prowadzono je w warunkach szklarniowych.

\section{WYNIKI}

Średni IFK w Cerekwicy wyniósł 6,9\% (0-33,0\%), natomiast w Radzikowie 9,0\% (0,5-30,0\%). Najwyższą odporność wykazały wzorce odporne oraz genotypy: KBP04.164, KBP05.284, NAD13014, NAD13015, NAD13016, NAD13017, POB0316, POB457/07, POB759/04 i STH9059.

Średnia odporność typu 1 wyniosła 1,54 punktów infekcji (pi) (1,00-2,89 pi). Najwyższą odporność typu 1 wykazał wzorzec odporny: 20816/2[Fhb1+] oraz genotypy NAD13015, KBP10 40, NAD13014, POB0211, POB0114, STH105, NAD11053, NAD13024, NAD13017, POB759/04, DC332/09-3, DCh4763/07, POB0616. Średnia odporność typu 2 wyniosła 1,89 porażonych kłosków (pk) (0-6,71 pk). Najwyższą odporność typu 2 wykazało 10 wzorców odpornych oraz genotypy STH032 i KOH275. Najwyższą średnią odporność obu typów wykazało 9 wzorców odpornych. Wysoka była również odporność następujących genotypów: STH2041, NAD13016, POB0514, NAD13017. Średnia odporności obu typów korelowała istotnie z IFK warunkach polowych $(\mathrm{r}=0,632)$.

Analiza składowych głównych, w której zmiennymi były IFK z lokalizacji (Poznań, Radzików, Dębina, Nagradowice, Polanowice) pozwoliła na zidentyfikowanie genotypów wykazujących odporność na porażenie kłosa we wszystkich środowiskach. Były to np.: AND82/11/50, POB1016, POB1216, NAD14008, STH5483, AND532/11, AND245/13, STH4317, POB0616, POB0216, POB0816, POB0516, SMH9523, NAD14020, 
POB0316, STH5407, KBP296/48, SMH9326, STH5485, DM850/14. Najwyższą odporność spośród wzorców wykazała odmiana Kilimanjaro.

Średnie uszkodzenie ziarniaków przez Fusarium wyniosło FDK masa $=14,3 \%$ $(2,6-43,2 \%)$ oraz FDK liczba $=21,1 \%(3,7-52,4 \%)$. Najniższe uszkodzenie ziarniaków miało 21 genotypów w tym 7 wzorców odpornych. Były to np. STH 9059, NAD 13014, NAD 13017, POB 170/04, NAD 14008, STH 5261, STH 5316. IFK korelował istotnie z uszkodzeniem ziarniaków.

Redukcja plonu ziarna z kłosa (RMZK) wyniosła średnio 45,6\% 90-86,4\%). Liczba ziarniaków w kłosie (LZK) została zredukowana średnio o 33,2\% (0-81,5\%). Masa tysiąca ziarniaków (MTZ) została zredukowana średnio o 20,9\% (0-54,9\%). Najniższą redukcję MZK w odniesieniu do kontroli odnotowano u 7 wzorców odpornych, odmiany Artist oraz 11 genotypów (w tym: AND82/11/50, STH9059, POB0316). Średni indeks fuzariozy kłosów oraz FDK korelowały z redukcjami masy ziarna z kłosa i liczby ziarniaków w kłosie.

Zidentyfikowano genotypy łączące odporność na porażenie kłosa (typ 1+2), uszkodzenie ziarniaków (typ 3) oraz niską redukcję plonu ziarna (typ 4). Były to: STH9059, POB0316, NAD13014, KBP1629, STH5261 oraz część wzorców odpornych.

W wybranych próbach pszenicy z 2017 koncentracja DNA F. culmorum wyniosła średnio 28034 pg na $1 \mu \mathrm{g}$ DNA pszenicy. W próbach z Poznania zawartość DNA (39117

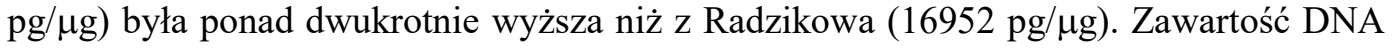
korelowała istotnie $\mathrm{z}$ innymi miernikami oceny odporności pszenicy na fuzariozę kłosów. Bardzo wysokie były współczynniki korelacji z IFK i FDK.

Średnia zawartość deoksyniwalenolu (DON) w ziarnie badanych genotypów wynosiła $1495 \mu \mathrm{g} / \mathrm{kg}(58-7726 \mu \mathrm{g} / \mathrm{kg})$. W próbach z Poznania zawartość DON była bardzo niska i wyniosła $595 \mu \mathrm{g} / \mathrm{kg}(23-8300 \mu \mathrm{g} / \mathrm{kg})$. W Radzikowie natomiast była 4-krotnie wyższa i wynosiła $2395 \mu \mathrm{g} / \mathrm{kg}(0-13825 \mu \mathrm{g} / \mathrm{kg})$. Stwierdzono obecność w ziarnie pszenicy pochodnych acetylowych DON - 3AcDON i 15AcDON. Zawartości tych toksyn były bardzo niskie. Średnia zawartość niwalenolu (NIV) w ziarnie badanych genotypów była wyższa niż zawartość DON i wynosiła $2778 \mu \mathrm{g} / \mathrm{kg}(353-8173 \mu \mathrm{g} / \mathrm{kg})$. W próbach z Radzikowa zawartość NIV była bardzo niska i wyniosła $67 \mu \mathrm{g} / \mathrm{kg}(0-375 \mu \mathrm{g} / \mathrm{kg})$. W Poznaniu natomiast była bardzo wysoka i wynosiła $5488 \mu \mathrm{g} / \mathrm{kg}(680-16295 \mu \mathrm{g} / \mathrm{kg})$.

Średnia sumaryczna zawartość trichotecenów $\mathrm{z}$ grupy $\mathrm{B} \mathrm{w}$ ziarnie genotypów pszenicy wynosiła $4338 \mu \mathrm{g} / \mathrm{kg}$. Zakres zmienności od 840 (S10[Fhb1+]) do $14465 \mu \mathrm{g} / \mathrm{kg}$ (POB0416).

Zawartość ZEN w ziarnie była niska i wynosiła średnio $45 \mu \mathrm{g} / \mathrm{kg}(0-454 \mu \mathrm{g} / \mathrm{kg})$. W próbach ziarna $\mathrm{z}$ Poznania stwierdzono jedynie średnio $17 \mu \mathrm{g} / \mathrm{kg} \mathrm{ZEN}$, natomiast w próbach z Radzikowa zwartość ZEN wynosiła $73 \mu \mathrm{g} / \mathrm{kg}$.

Ze względu na znaczne różnice w porażeniu kłosów genotypów badanych w dwóch doświadczeniach z Radzikowie, analizowano ich wyniki oddzielnie. Analiza wieloczynnikowa wykazała, że w grupie odpornych najniższą akumulację różnych grup toksyn stwierdzono u wzorców odpornych (z wyjątkiem Ariny i Fregaty) oraz u genotypów POB0114, NAD13014, STH9059, NAD13024 i AND82/11/50, AND4019/14, POB0111, 
NAD13024, AND4023/14, POB679/03, NAD13017, POB0616 (rys. 1). W grupie DW najniższą akumulację różnych grup toksyn stwierdzono u genotypów STH6151, STH5347, STH6130, NAD15105, STH6116, STH6167， STH6177， NAD15115, STH5261, POB0517, STH6177, STH6167 i STH6111 (rys. 2).

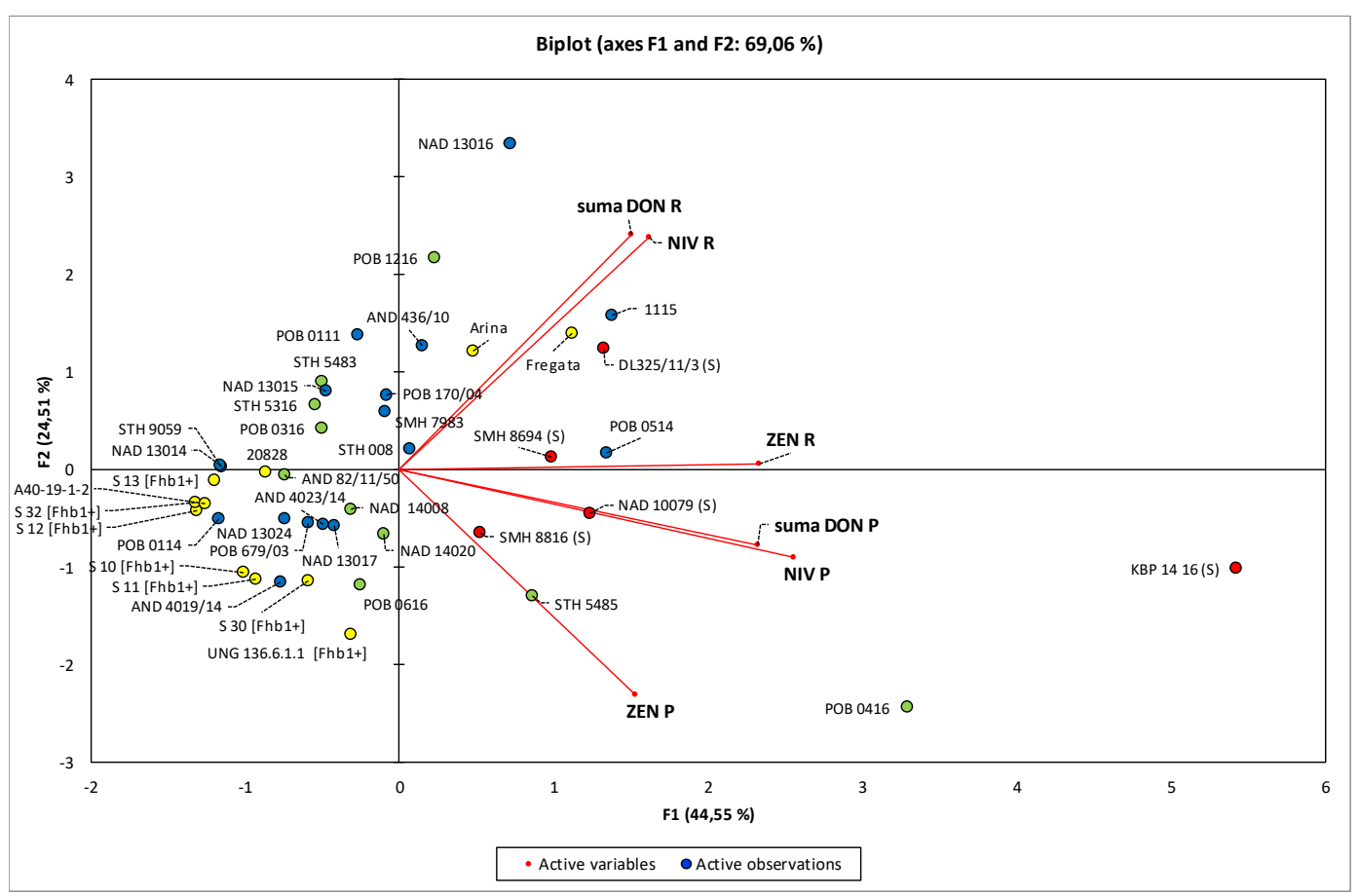

Rys. 1. Układ wspólrzędnych dwóch składowych głównych dla 43 genotypów pszenicy ozimej z grupy 'odporne'. Składowe wyjaśniają 69,06\% zmienności odporności akumulację zearalenonu (ZEN) i trichotecenów z grupy B (suma DON, NIV) w ziarnie z doświadczeń w Poznaniu (P) i Radzikowie (R). Wektory wskazują kierunek wzrostu wartości zmiennych

Indeks fuzariozy kłosów korelował istotnie z zwartością trichotecenów oraz zearalenonu. Najniższy był współczynnik korelacji z 15AcDON, najwyższy dla ZEN. Uszkodzenie ziarniaków nie korelowało z zawartością DON, natomiast wysokie były współczynniki korelacji z zawartościami NIV i ZEN. Stężenie DON nie korelowało istotnie z zwartością NIV. Istotny, lecz niski był współczynnik korelacji ze stężeniem ZEN.

W wyniku selekcji we wszystkich populacjach zidentyfikowano łącznie 166 osobników homozygotycznych w loci markerów centralnych (UMN10 lub cfb6033) sprzężonych z genem odporności na fuzariozę kłosów $F h b 1$. Wśród tej grupy znalazło się 135 roślin homozygotycznych (w typie rodzica wypierającego) w locus flankującego proksymalnie markera gpw3248 (27 w locus markera gwm493) oraz 75 osobników homozygotycznych w locus markera flankującego dystalnie — gwm389 (47 w locus markera barc12). Najbardziej pożądanym układem alleli był natomiast układ: 
homozygota $\mathrm{w}$ typie rodzica dawcy $\mathrm{w}$ locus markera centralnego oraz homozygoty w typie rodzica wypierającego w loci markerów flankujących.

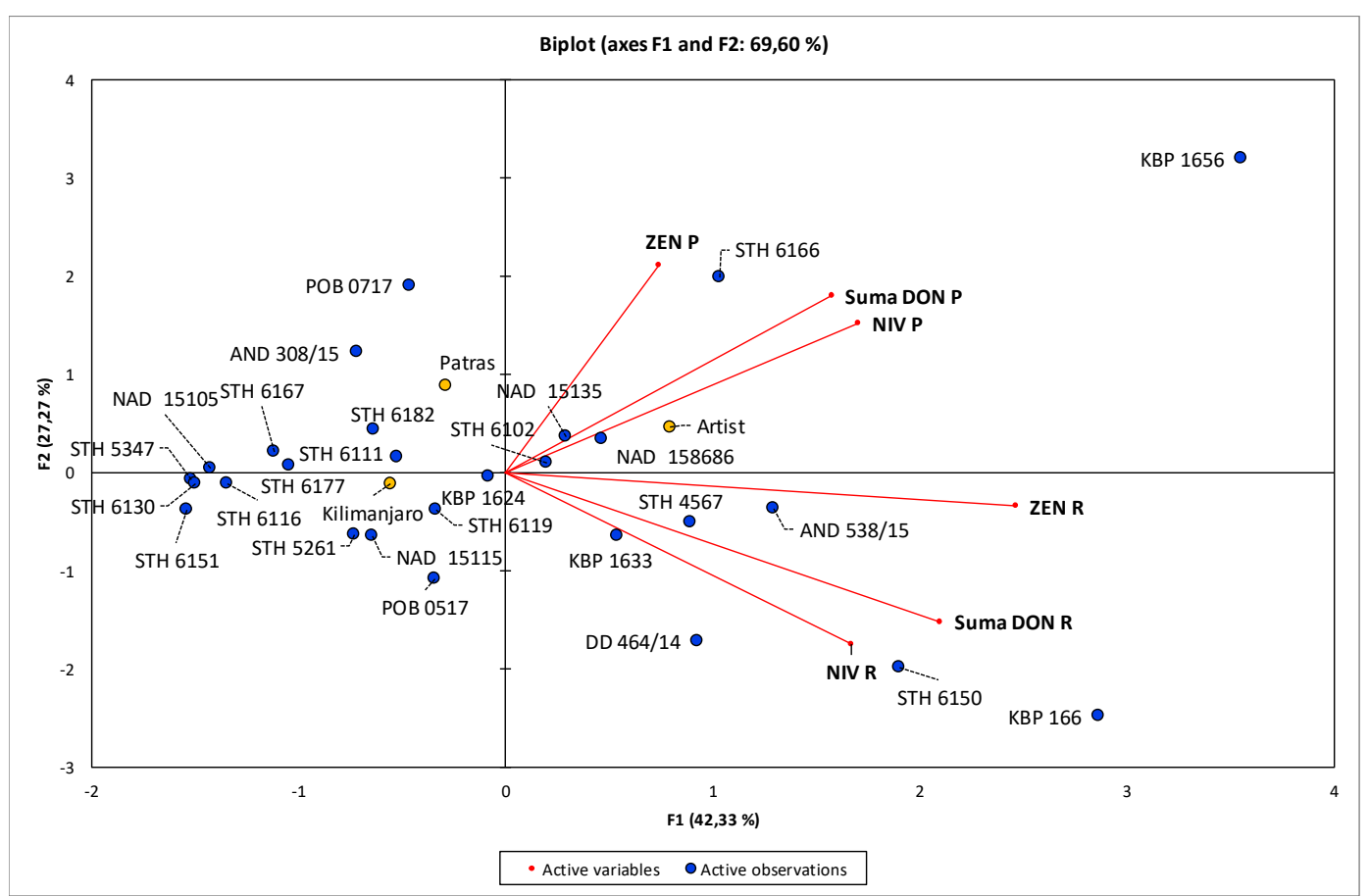

Rys. 2. Układ współrzędnych dwóch składowych głównych dla 30 genotypów pszenicy ozimej z grupy 'DW. Składowe wyjaśniają 69,60\% zmienności odporności akumulację zearalenonu (ZEN) i trichotecenów z grupy B (suma DON, NIV) w ziarnie z doświadczeń w Poznaniu (P) i Radzikowie (R). Wektory wskazują kierunek wzrostu wartości zmiennych

Po zakończeniu analiz wybrano 55 roślin, które posłużyły do uzyskania pokolenia $\mathrm{F}_{3} \mathrm{BC}_{2}$. Każdą $\mathrm{z}$ kombinacji potraktowano indywidulanie pod względem kryteriów selekcji osobników do dalszego rozmnażania, wybierając te o wcześniej wspomnianej najlepszej kombinacji alleli. Dodatkowo, w każdej kombinacji zebrano nasiona z ośmiu roślin homozygotycznych w typie rodzica wypierającego zarówno w locus markera centralnego, jak i w loci markerów flankujących. Rośliny te będą stanowić grupę kontrolną w przyszłych doświadczeniach infekcyjnych.

\section{LITERATURA}

Argyris J., Van Sanford D., TeKrony D. 2003. Fusarium graminearum infection during wheat seed development and its effect on seed quality. Crop Sci. 43: $1782-1788$.

Góral T., Wiśniewska H., Ochodzki P., Nielsen L. K., Walentyn-Góral D., Stępień Ł. 2019. Relationship between Fusarium head blight, kernel damage, concentration of Fusarium biomass, and Fusarium toxins in grain of winter wheat inoculated with Fusarium culmorum. Toxins 11: 2. 
Nicolaisen M., Suproniene S., Nielsen L. K., Lazzaro I., Spliid N.H., Justesen A. F. 2009. Real-time PCR for quantification of eleven individual Fusarium species in cereals. Journal of Microbiological Methods 76: $234-240$.

Perkowski J., Buśko M., Stuper K., Kostecki M., Matysiak A., Szwajkowska-Michałek L. 2008. Concentration of ergosterol in small-grained naturally contaminated and inoculated cereals. Biologia 63 (4): $542-547$.

Perkowski J., Wiwart M., Buśko M., Laskowska M., Berthiller A., Kandler S., Krska R. 2007. Fusarium toxins and total fungal biomass indicators in naturally contaminated wheat samples from northeastern Poland in 2003. Food Additiv. Contam. 24 (11): 1292 - 1298. 
